\title{
Structural Study of the EDDA Igbo Folktales
}

\author{
Mercy Agha Onu ${ }^{1}$, Ngozi U. Emeka-Nwobia ${ }^{2}$ \\ ${ }^{1,2}$ Department of Linguistics and Literary Studies Ebonyi State University, Abakaliki
}

\begin{abstract}
This work is a comparative study of the discoveries of Vladimir Propp study of Russian folktales and Edda Igbo folktales. The study hinges on Propp's Morphology of Folktales, which has rightly been accepted all over the world as a classic. Thus, the study tends to determine the relatedness between Propp's findings in Russian folktales and that of the Edda Igbo folktales. The discoveries Propp made includes the identification of the dramatis personae in folktales, the assigning of names to the functions of the dramatis personae, the artistic arrangement of the functions or actions in the narratives among other things. In order to make assurance doubly sure, we used the Morphology of Folktales to find how the actions and functions rhyme with Edda Igbo examples. For the study, three tales collected orally were analyzed. The theoretical framework adopted for the study is structuralism. From the findings, we observed similarity between Propp's dramatis personae and Edda Igbo folktales. Also, instances of aggregation of actions and stability of actions were noticed in Edda.
\end{abstract}

\section{INTRODUCTION}

Folktale is a story passed down orally from generation to generation. This has to confirm the theory of Polygenesis or Evolutionist school of thought which holds that oral literature all over the world started spontaneously all over the world.It is an established fact that story telling is universal. There is no culture that does not tell stories. A folktale can be seen as a story or legend handed down from generation to generation usually by oral medium. Folktale is a mirror of the society. It explains some mysteries as Achebe (1987, p.15) explains that a story "does many things. It entertains, it informs, it instructs". That is why it continues to exist and that is why the content of folktale remains stable.

African proverbs and stories draw upon the collective wisdom of oral peoples, express their structures of meaning, feeling, thought and expression and thus serve important social and ethical purposes. Iyasere (1975,p.105) puts it as follows, "the story itself is a primary form of the oral tradition, primary as a model of conveying culture, experience and values and as a means of transmitting knowledge, wisdom, feeling and attitudes in oral societies".

Folktales are popular among the Igbo as well as people all over the world and fulfils the same functions all over the world.

Edda is one of the dialect groups in Ebonyi State. Edda people like other counterparts love story telling. This is because storytelling is one of the principal avenues for informal education and entertainment for children in the traditional Igbo society.

\section{METHODOLOGY}

In terms of methodology, the ethnographic method was adopted. Some elders reputed for their skills in story telling in the community were purposively chosen as our informants. We also discovered some young men who are versatile in folktales and were asked to give a rendition of some Edda Igbo folktales. This crop of people became the live-library for our investigation, informants. Our research instruments involved tape recorder, for taping the information, batteries, pen, jotters, camera and a research assistant. The tapes were transcribed with parallel English translations.

The library became a second source of our methodology.We searched for works mainly on structuralism using Vladimir Propp's Morphology of Folktales as our tool for the analyses of three selected folktales from the field, they are: "Iyi Ogba", "Ife mere Mbe ji nworo mkpokoro azu" and "Oriri Mbe yara итиппипи”.

\subsection{Empirical Studies}

\section{LITERATURE REVIEW}

A review of literature reveals that many scholars have delved into the studies of folktales in Igbo. We focused on some studies that are relevant to this investigation and they include: Azuonye (1990),Eze (2000) Ikeokwu (2007), Nwaozuzu (2007), Iwuchukwu (2008), Ogbalu (2011), Aku (2012), and Edeoga, (2015).

Azuonye (1990) examines the morphology of the Igbo folktale. He analyzed two Igbo folktales using the fixed progressive sequentially suggested by Propp (1928). According to Azuonye (1990, p.7), "there are 
many apparent violations which at times suggest that we may be better off using the paradigmatic models to fully appreciate the antinomies of good and evil etc. of which the tales are composed. However, there are a number of tales in which the predicted Propp's patterns are almost perfect". He explains further "the morphological structures of tales are best captured by the use of the Propp's approach". He therefore analyzed the morphological structures of two such tales. The first 'Obaraedo' is a one-move tale, while the second 'Omalinze' is a two-move tale. He identified that folktales are rich stories of cultural value and should be preserved.

Eze (2000) carries out a study on Igbo folktales using Propp's syntagmatic model. She worked on ten tales types and discovered that they fit into Propp's structure of folktales. They are: the first tale 'An oppressed orphan' is a two move tale which the first move has six functions while the second move has seven functions. The second tale 'A girl who rejects many suitors' has ten functions, the third tale Obaraedo has thirteen, the fourth 'Ojaadilị' has two moves the first move has five, the second move ten functions. The fifth tale 'Omalinze' is a two move tale; the first move has nine, the second move has twelve; the sixth tale 'The jealousy women' has twenty three functions; the seventh tale 'The tiger and his wives' ten functions; the eighth tale 'The Tortoise and the snail' a three tale move; move one has five functions and second move has seven functions while the third move nine functions; the ninth tale 'The Tortoise and the ant' has twelve functions; the tenth tale has 'How death came on Earth has eleven functions. She concluded that the functions of the dramatis personae can be used to account for the behavioural patterns of motivation and conduct of the Igbo. She also deduced why certain functions continue to reoccur in Igbo folktales functions like absentation, violation, villainy, lack and exposure have purposely been weaved into folktales, possibly to reach and instruct the public on how to tackle most of the issues they encounter in their daily interactions. From this, it could be deduced that folktales are mirrors of the societies in which they are told.

Iwuchukwu (2008) carries study on the folktales of Oraifite using propp's model of structural analysis. He found out that the model fits into the folktales of Oraifite. He analyzed ten folktales; they are: Onwuelo has nine functions, Miri Ezeọba has sixteen functions, Ndị mmụọ na Nwaọba has fourteen, Ụmụanumanụ jere nta has eight, Agụ na Mbe has nine, Nwanyị na-akpọ dị ya ife a has nine, Ele jere mgba n'obodo Ụmụanụmanụ has six, Mbe lụrụ Ada Eze has four, Dinta na Nkenu has five functions while Eze Olibaba has nine functions. He concluded that Propp's structural theory can be best used in Oraifite folktales as well as Igbo folktales.

Ogbalu (2011) studies Igbo folktales and songs versus realism. The author feels that there must be some natural compelling forces behind this phenomenon which make the Igbo appreciate their folktales as if they were true life stories. The study identifies these forces that make the Igbo love their folktales so much. He observes that when one reads or listens to fictitious story, there is a type of feeling or impact it makes on the listeners. This feeling makes the appreciator react voluntarily or involuntarily to the story. They are voluntary appreciation and involuntary appreciation. He further states that the voluntary appreciation is the type of appreciation that occurs when an appreciator has willingly suspended his disbelief and accepted all he heard as real. He identifies that song in Igbo folktales makes this stories to be interesting and easily remembered and that these features are necessary to relate such stories to realism.

Aku (2012) studies folktales in Caribbean societies. He focuses on their content. He interviewed some old people in some cities in the Caribbean. He identifies that the folktales are carriers of the culture and values of the Caribbean. In terms of structure, he holds that songs are not part of the folktales but use of paralinguistic gestures such as head, hand, eye and other body movements. This he found is a major variation in the folktales studied.

Edeoga, (2015) analyzes the Igbo folktale 'Odụ na Ọna' using Propp's(1928) structural analysis; she identified sixteen functions in the tale. They include among others: Absentation $\beta$ : A member of the family leaves the security of the home environment. This may be the hero or some other member of the family that the hero will later need to rescue. This division of the cohesive family injects initial tension into the story line. The hero may also be introduced here, often being shown as an ordinary person. Interdiction $\square$ (gamma): An interdiction is addressed to the hero ('don't go there', 'don't do this'). The hero is warned against some action (given an 'interdiction'). Violation of interdiction $\square$ (delta): The interdiction is violated (villain enters the tale). This generally proves to be a bad move and the villain enters the story, although not necessarily confronting the hero. Perhaps they attack the family whilst the hero is away. Reconnaissance $\square$ (epsilon): The villain makes an attempt at reconnaissance (either villain tries to find the children/jewels etc.; or intended victim questions the villain). The villain (often in disguise) makes an active attempt at seeking information, for example searching for something valuable or trying to actively capture some. They may speak with a member of the family who innocently divulges information. They may also seek to meet the hero, perhaps knowing already the hero is special in some way. Delivery $\square$ (zeta): The villain gains information about the victim. The villain's seeking now pays off and he or she now acquires some form of information, often about the hero or victim. Other information can be gained, for example about a map or treasure location. Trickery $\square$ (eta): The villain attempts to deceive the victim to take possession of victim or victim's belongings (trickery; villain 
disguised, tries to win confidence of victim). The villain now presses further, often using the information gained in seeking to deceive the hero or victim, getting the hero to give the villain something or persuading them that the villain is actually a friend and thereby gaining collaboration.

\subsection{Theoretical Framework}

The theoretical framework underlying this study is the Structuralist theory by Propp, (1928). The theory states that "Structuralism is the study of the inter-relationships or organization of the component parts of an item of folklore" (Dundes, 1976, p.67). The most influential theory to emerge in the folklore studies in the 1960s was the structural theory and it dominates the current trends in folklore studies. Although the germs of structural or pattern approach can be traced to the works of Raglan, Olrik, Von Sydow, Andre Jolles etc. but the real beginnings of structural study appeared when a Russian Formalist, Vladimir Propp developed an analysis that reduced Russian fairy tales to a series of actions performed by the dramatis personae in his book Morfologiya skazki (Morphology of Folktale) which was first published in 1928. This work unfortunately had to wait thirty long years for recognition because it was not translated into English until 1958 and again the diachronic attitudes in Russia and other places were also responsible for ignoring this work which was primarily based on synchronic principles. By the time its translation appeared in 1958 there was a little change in the attitudes of folklorists and scientific thought had begun taking roots in folklore theory and methodology. Propp(1928) argues that all fairy tales are composed of certain plot elements which he calls functions and that these elements consistently occur in a uniform sequence. Based on his study of one hundred folktales, Propp (1928) devised a list of thirty one motifemic functions, proposing that they encompassed all of the plot components from which fairy tales were constructed.

Dorson (1972) posits that Propp has been described as "the true father figure of the Structuralist (formalist) movement, and he purposely introduce his scheme to displace the taxonomy of Antti Aarne". He goes further to say that "although Jason notes that Propp may have borrowed some of his ideas from Nikiforov's (1927) essay 'on the morphological study of folklore', there is no doubt that the publication in Russia in 1928 of his book 'The morphology of the folktale' and its translation to English in 1958 marked a revolution in the method of folktale analysis all over the world.

These are the conceptual definitions of the thirty one functions:

1. ABSENTATIONB: A member of the family leaves the security of the home environment. This may be the hero or some other member of the family that the hero will later need to rescue. This division of the cohesive family injects initial tension into the story line. The hero may also be introduced here, often being shown as an ordinary person.

2. INTERDICTION $\square$ (gamma): An interdiction is addressed to the hero ('you dare not look into this closet', 'don't go there', 'don't do this'). The hero is warned against some action (given an 'interdiction').

3. VIOLATION OF INTERDICTION $\square$ (delta): The interdiction is violated (villain enters the tale). This generally proves to be a bad move and the villain enters the story, although not necessarily confronting the hero. Perhaps they attack the family whilst the hero is away.

4. RECONNAISSANCE $\square$ (epsilon): The villain makes an attempt at reconnaissance (either villain tries to find the children/jewels etc.; or intended victim questions the villain). The villain (often in disguise) makes an active attempt at seeking information, for example searching for something valuable or trying to actively capture some. They may speak with a member of the family who innocently divulges information. They may also seek to meet the hero, perhaps knowing already the hero is special in some way.

5. DELIVERY $\square$ (zeta): The villain gains information about the victim. The villain's seeking now pays off and he or she now acquires some form of information, often about the hero or victim. Other information can be gained, for example about a map or treasure location.

6. TRICKERY $\square$ (eta): The villain attempts to deceive the victim to take possession of victim or victim's belongings. The villain uses persuasion (trickery; villain disguised, tries to win confidence of victim). The villain now presses further, often using the information gained in seeking to deceive the hero or victim, getting the hero to give the villain something or persuading them that the villain is actually a friend and thereby gaining collaboration.

7. COMPLICITY $\square$ (theta): Victim taken in by deception, unwittingly helping the enemy. The trickery of the villain now works and the hero or victim naively acts in a way that helps the villain. This may range from 
providing the villain with something (perhaps the villain has persuaded the hero that these other people are actually bad).

8. VILLAINYA: Villain causes harm or injury to family member (by abduction, theft of magical agent, spoiling crops, plunders in other forms, causes a disappearance, expels someone, casts spell on someone, substitute child etc. demands or entices the victim, commits murder, imprisons/detains someone, threatens forced marriage, provides nightly torments); Alternatively, a member of family lacks something or desires something (magical potion etc.).In this function there are two options, either or both of which may appear in the story. In the first option, the villain causes some kind of harm, for example carrying away a victim or the desired magical object identified, for example in the hero' family or within a community, whereby something is identified as lost or something becomes desirable for some reason, for example a magical object that will save people in some way.

9. MEDIATIONB: Misfortune or lack is made known, (hero is dispatched, hears call for help etc. / alternative is that victimized hero is sent away, freed from imprisonment). The hero now discovers the act of villainy or lack, perhaps finding their family or community devastated or caught up in a state of anguish and woe.

10. BEGINNING COUNTER-ACTIONC: Seeker agrees to, or decides upon counter-action. The hero now decides to act in a way that will resolve the lack, for example finding a needed magical item, rescuing those who are captured or otherwise defeating the villain. This is a defining moment for the hero as this is the decision that sets the course of future actions and by which a previously ordinary person takes on the mantle of heroism.

11. DEPARTURE $\uparrow$ (up-arrow): Hero leaves home

12. FIRST FUNCTION OF THE DONOR testing D: Hero is tested, interrogated, attacked etc., preparing the way for his/her receiving of magical agent or helper (donor).

13. HERO'S REACTION: E: Hero reacts to actions of future donor (withstands/fails the test, frees captive, reconciles disputants, performs service, uses adversary's power against him).

14. RECEIPT OF MAGICAL AGENT (Acquisition) F: Hero acquires use of a magical agent (directly transferred, located, purchased, prepared, spontaneously appears, eaten/drunk, help offered by other characters.

15. GUIDANCEG: Hero reaches destination. Hero is transferred, delivered or led to whereabouts of an object of the search.

16. STRUGGLEH: Hero and villain do battle.

17. BRANDINGJ: Hero is branded (wounded/marked, receives ring or scarf).

18. VICTORYI: Villain is defeated (killed in combat, defeated in contest, killed while asleep, and banished).

19. RESOLUTION K: Initial misfortune or lack is resolved

20. RETURN $\downarrow$ (down arrow): Hero sets out for home.

21. PURSUITPr: Hero is pursued (pursuer tries to kill, eat, and undermine the hero.

22. RESCUERs: Hero is rescued from pursuit (obstacles delay pursuer, hero hides or is hidden, hero transforms unrecognizably, hero saved from attempt on his/her life.

23. ARRIVALO: Hero arrives home unrecognized.

24. CLAIML: False hero makes proposed to the hero

25. TASKM: Difficult task proposed to the hero.

26. SOLUTIONN: Task is resolved

27. . RECOGNITIONQ: Hero is recognized.

28. EXPOSUREEx: False hero is exposed.

29. TRANSFIGURATION T: Hero is given a new appearance.

30. PUNISHMENTU: Villain is punished.

31. WEDDING W: Hero marries and ascends the throne.

Propp's (1928) approach to the analysis of the folktale is to identify and define a morphological unit which he termed "function" i.e. defined by their sequence in the plot". The function then is the unit of plot narrative structure and is the most constant and invariable part of the narrative.

His working steps are:

a. To go through each tale, noting every action that occurs.

b. To give every action a descriptive name this is a noun denoting the action. 
c. To observe the place of the action in the process of narration noting especially the motivation or consequences of an action.

d. By using letter notation in place of the 'function', he is able to delineate the structure of all Russian fairy tales, and to make a structural typological statement on them.

Propp's(1928) intention in constructing the model was to displace the taxonomic scheme of Antti Aarne (in what is widely known today as the Aarne-Thompson index) in which tales are classified according to their dramatis personae, but on certain highly stylized and recurrent types of an action which regularly occur in fixed (generally predictable) pattern and which are fulfilled by many different kinds of characters in a wide variety of situations and setting. To these recurrent types of action Propp gives the name 'function' of the dramatis personae. From his anatomy of 100 Russian tales from famous Afanasev collection, Propp surmised that the functions of the dramatis personae are not only the building-blocks of the fairy tale but that they are limited in number.

For the Russian fairytale tradition, he identified 31 functions, to each of which he assigned an alphabetical or graphic code. However, since there are thousands of tale types in any folktale tradition, it follows that each tale or tale-type in the tradition will be a unique selection and combination of functions, from such a limited stock of functions. Thus, while the actual character, situations and setting presented in two or more tales differ considerably, the tales themselves may exhibit the same pattern if they contain the functions in the same order.

Propp's (1928) examination of such patterns resulted in his formulation of hypothesis of the fixed progressive sequentially of the functions of the dramatis personae. A tale can begin with any function (e.g. Interdiction or lack): but, in the advancement of its plot, neither this initial function nor any other subsequent function included or omitted can be repeated thus in the series above $1,2,3,4,5,6,7,8,9,10 \ldots$ the same order is always followed strictly in every tale, even if one or two functions are omitted. An antecedent function can never occur after any subsequent one. Thus we can have the series $2,3,6,10,12,14$ or $1,3,7,8,11$ but never $2,1,6,4,2$ or any other in which an antecedent function comes after a subsequent one. The only exceptions are tales in two or more moves (or parts) in which for practical purposes each move constitute a complete morphological unit with its own distinctive internal pattern of functions. As has been pointed out above, Propp's morphology was essential intended as a taxonomic scheme. First, it distinguished the 'Volsebnaja Skazki' (fairy tale) from the other kinds of the Russain folktale. The 'Volsebanaja Skazki' (which is in the same generic class as the Igbo folktale) is, in other words, the only kind of the folktale, which contain the functions of the dramatis personae, exhibiting the structural features subsumed under the hypothesis of the fixed linear sequentially of functions. No other type of the tale will exhibit similar features.

The main features of Propp's(1928) model are summed up as follows in The Morphology of the folktale(1946, pp.21-23). Function is understood as an action of a character, defined from the point of view of its significance for the course of the action.

1. Functions of characters serve as stable constant elements in a tale, independent on how and by whom they are

fulfilled. They constitute the fundamental components of a tale.

2. The number of functions known to the folktale is limited.

3. The sequence of functions is always identical.

4. All folktales are of one type in regard to their structure.

Propp studies the structure of folktales of Russia. He found out that there are thirty one functions of the dramatis personae in the Russian folktales. He calls these dramatis personae. These according to him appear in a rigid order, such that if in a tale, one does not appear where it is supposed to appear, it will never appear again in the tale.

Dundes (1976) identifies himself with this definition when he says "that structuralism is the study of the inter-relationships or organization of the component parts of an item of folklore". He goes further than Propp by declaring that this method of analysis is not limited to narrative genre but is also applicable to minor genres like proverbs, riddles, superstition etc. and he has actually analyzed many of these genres using the structural approach.

\section{STRUCTURAL ANALYSIS OF SOME EDDA TALES}

\section{(a) Components of the Edda Igbo folktale}

An examination of the structure of Igbo shows that word groups of Igbo folktales abound. The words used to introduce folktale are formulas. They serve as key to the imaginative world of the folktales.Folktales in Igbo begin with repartees between the audience and the narrator, the repartees vary from one culture to the other but each of them serve to launch the audience into the mystical world of folktale (Mbah and Mbah (2007, p.122)). 
The common repartees in Edda as well as Igbo generally are:

Ọkọakụkọ: Nkita nyara akpa:(If a dog carries a bag).

Ndịogige: Nsi agwụ nnọ:(Feaces finish in the toilet).

Ọkọakụkọ: Mini riri ụgbala: (The river that drowns a duck).

Ndịogige: Adighị egu ya egu: (It is not swimmable).

Ọkọakụkọ: Ọịa ogwu mara ọụkụ: (The bush where a thorn pinches a hen).

Ndịogige: Adịhị e pie ya epie: (Nobody enters it).

Ọkọakụkọ: O nwere akụkọ m ga-akọrọ unu: (I have a story to tell you).

Ndịogige: Kọoro anyị ka obi dị anyị mma: (Tell it to us so that our heart will be merry).

Okọakụkọ: O ruru otu mgbe: (Once upon a time).

Ndịogige: Mgbe ruo: (Time time).

The above solo- chorus repartees among others according to (Mbah and Mbah 2007, p.123) serve as an entry behaviour. They are to awaken the thought of the audience and at the same time, to keep them in suspense. After the repartee, the narrator tells the audience the essence of the business. He tells them what he has for them and they chorus "tell us so that our hearts will be merry".

The theme or lesson of the narrative might, at the end, be counted in an etiological element or a moral or didactic formula. If the story ends in moral formula the final conclusion is always $O$ ya mere(that's why...) and if it ends in a didactic note, the storyteller ends it with Ife ozizi ya bụ... (What it teaches is...).

Another feature of folktale is the theme; theme means essence of the narrative piece. It is the picture created by means of words and encapsulated in a literary composition. The picture may be a character and such a picture could be conjured by epithets, tittles, and mock-heroic and satiric names. It may be the picture of nonspecific fictional world in both time and place. Theme may also be an action or what a character does. Actions in the folktales are called functions of the characters or dramatis personae. They begin from absentation or interdiction etc. Anotheruniversal feature of folktale is the song. The songs in the tale tend to highlight moments of intense emotion as in the tale below. We therefore in this study analyze some Edda Igbo folktales based on the tenets of Propp's (1928) Structural Model as to substantiate or otherwise the claims or tenets of this theory.

\section{b) Some folktales and their Structural Analysis}

\subsection{Tale one: Iyi Ogba}

Oruru otu mgbe; mgbe erue, Nwoko olu luru ụmụ nwaami abụọ, onye nke mbu mutara nwaamị onye nke abụọmụta nwa nwoke. Ka obi adị nke ọ hụ amụtaghịnwoke mma ebe mie dị ya nọ.ka o zipụta miedi ya eleghi obi adịhị ya mma. Oru a abalị olu ka onye nke ọhụ mụrụ nwoke e nwo mini o ji echo nwa ya. Ya je kuru mini mie dị ya gwere chuo nwa ya. Mgbe miedị ya lọtara chọpụta eleghị miedị ya kuuru mini ya nye nwa ya. yọ si ọ makwa kushihiara ya mini ọhụ. Yọ je kutara ya mini Ọgbaagụ yọ ju si ọ makwa bụrụ mini Iyiọgba. Iyiọgba bụkwa iyi ojọo da- akpa ike mgbe dum karịdua mgbe abalị. Miedi ya sikwahụ o makwa chua iyi ọ̣ụ. Mgbe o chughere ọtụtụ ife egwu dị icho icho mere ụzọ ime egwu tụa ya. Mgbe o rutara mini iyiọgba agbọghọ mini pụta. Nwami ọhụ gụịị ya iri a:
Ọ ma mma chere mkpaịị ị- Inine!
Ò ma mma chere m kpaịị ị- Inine!
Miedi m dị njọ - Inine!
M kuru mini m ji enye nwa - Inine!
O si m kwo ya uggwo mini mini nwa - Inine!
M kutara ya Oggbaagu - Inine!
Ọ sị ma ọ bụghị Iyiọgba Ọ maghị eji- Inine!
Ebe mini siri warawara laa eluigwe - Inine!
Inine ogogo! Inine Ogogo! Inine ogogo!- Inine!
Inine ogogo! Inine ogogo! Inine ogogo!- Inine!

Mgbe ọ gụduru abụ a agbọghọ mini ọhụ meare ya ebere buyi ite mini abụọ nke ukwu yara nke nta si ya buru olu la, yọ buru nke ka nta, yọ si ya ọ larụa ulo ya kụwaa ite ọ̣ụ ifu ulo wọ. Mgbe o larụtara ulo ya kụwaa ite ọụ ifu ezi, ife ọma dị ichoricho jupụta ulo wọ, anya ụfụ dị miedị ya, yọ dupu nwa nke ya gha o chu Iyiọgba. Mgbe nwa ya ruru Iyiọgba, Agbọghọ mini pụta kọọọ ya ọkụkọ, yọ kọgwara. Agbọghọ mini ọhụ buyi ya ite abụọ nke dị ukwua yara nke dị nta. Yọ jee buru ite nke ọhụ ka ukwua. Mgbe ọ larutara ulo yọ kụwaa ite ọhụ, ife ọjọo dị ichoricho pụta tagbudua wọdum.

Once upon a time, a man married two wives; the first wife gave birth to a baby girl while the other had a son. And the one that had a girl was not happy. And she never showed her co-wife that she was embittered. One day the one that had a male child did not have drinking water. She went and took a cup of water from her 
co-wife pot and gave to her child. When the co-wife's came back and found out that the woman took her water, she demanded that the woman must replace the water she took. She fetched water from Ogbaagu river but the co-wife refused to accept it and insisted that she must fetch water from the stream of Ogba. The stream of Ogba is a dangerous river mostly at night but the woman insisted that the co-wife must fetch from that stream. When she went to the stream the spirit water came out and the woman started singing to the mermaid.

Ọ ma mma chere m kpaịrịi - Inine!

Ọ ma mma chere m kpaịrịi- Inine!

Miedi m dị njọ - inine!

M kuru mini m ji enye nwa - Inine!

Ọ sị m kwọ ụgwọ mini mini nwa - Inine!

M kutara ya Oggbaagụ - inine!

Ọ sị ma ọ bụghị Iyiọgba O maghị eji- Inine!

Ebe mini siri warawara laa eluigwe - Inine!

Inine ogogo! Inine Ogogo! Inine ogogo!- Inine!

Inine ogogo! Inine ogogo! Inine ogogo- Inine!

After singing the river goddess had mercy on her and gave her two pots of different sizes to choose one and she chose the small pot and she asked her to smash it in front of their house. When she broke the pot good things came out and the co-wife was jealous and she sent her daughter to go to the stream of Ogba. When she reached the stream, the river goddess came and scolded her and she responded negatively, the river goddess gave her two pots a big one and a smaller one and ask to choose one and smash in front of their house. She preferred the bigger one to the smaller one. When she smashed the pot all sorts of things, snakes, scorpions, lizards and other dangerous things came out of the pot and killed them.

Reconnaissance $\square$ :(epsilon): The villain makes an attempt at reconnaissance

The tale starts with Reconnaissance, the villain (first wife) makes an active attempt at seeking information, the active attempt here is that of thinking or hearing of a delivery of a baby boy. The first wife hears of the second wife's delivery of a male child either by figment of imagination or by asking questions she starts bearing grudges in her mind. 4

Delivery $\square$ (zeta): The villain gains information about the victim.

Yes she (the villain) gains information about her co-wife's male child. The information is now confirmed that the co-wife gave birth to a male child. She becomes angry.5

Trickery $\square$ (eta): The villain attempts to deceive the victim to take possession of victim or victim's belongings (trickery; villain disguised, tries to win confidence of victim).

On gaining the information, she (first wife) presents facial deceit; she shows false pretense of being happy or false impression of being happy whereas in her heart she was full of animosity.

She conceals her true colour, her impression about the delivery of a male child. This is what Propp defined as trickery in other words the woman can be defined as a trickster.6

Complicity the Connective Incident $\square$ (theta):Victim taken in by deception, unwittingly helping the enemy. The trickery of the villain now works and the hero or victim naively acts in a way that helps the villain. Here the trickery of the villain works, the woman (the one that has a male child) is taken unaware, she didn't suspect anything. She thinks they are in a good relationship that is why she casually takes a cup of water from her cowife's pot to give to her son.7

Villainy A: Villain causes harm or injury to family member (by abduction, theft). This function is exceptionally important, since by means of it the actual movement of the tale is created. Absentation, the violation of an interdiction, delivery, the success of a deceit, all prepare the way for this function, create its possibility of occurrence, or simply facilitate its happening. Therefore the first seven functions may be regarded as the preparatory part of the tale, whereas the complication is begun by an act of villainy Propp, (1968, pp 30-31). The victim being taken by deception gives the villain room to make a near impossible demand which is that the second wife (the victim) goes to the river infested malevolentspirits to replace the water she takes from her pot. She succeeded in deceiving the second wife and therefore has the opportunity to ask for the impossibility. 8

Mediation B:This function brings the hero into the tale.Misfortune or lack is made known, (hero is dispatched, hears call for help etc. / alternative is that victimized hero is sent away, freed from imprisonment). The hero now 
discovers the act of villainy or lack, perhaps finding their family or community devastated or caught up in a state of anguish and woe.

The woman now discovers the act of villainy, under this situation she feels her life is in danger and she becomes afraid of the threat of the co-wife, she has no option than to leave to fetch the water. 9

Beginning counter-actionC: The Seeker agrees to, or decides upon counter- action. The hero now decides to act in a way that will resolve the lack. On finding out the hidden agenda of the villainy (the first wife) the woman now decides to act in a way that will resolve the lack by going to the spirit infested water to fetch the water. 10

Departure $\uparrow$ (up-arrow):Hero leaves home. She (the second wife) leaves for the river. 11

First function of the donor testing D:Hero is tested, interrogated, attacked etc., and preparing the way for his /her receiving of magical agent or helper (donor).

On reaching the spirit infested river, the river goddess interrogates her, she sings a sympathetic song that moves the goddess to have pity on her, and she (the river goddess) tested her by giving her two pots of different sizes to choose from. 12

Hero's Reaction E: Hero reacts to the actions of future donor (withstands/fails the test, frees captive, reconciles disputants, performs service, and uses adversary's power against him).

The woman seeing two pots of different sizes chooses the small pot thereby passing the test. This was a deliberate attempt to test her greediness or humility.13

Receipt of Magical Agent(Acquisition)F: Hero acquires use of a magical agent (directly transferred, located, purchased, prepared, spontaneously appears, eaten/drunk, help offered by other characters.

Here the river goddess hearing the story of the woman through her song and seeing that the woman has a good heart and not greedy,she gives her the pot and definite instructions on what to do.14

Resolution K: Initial misfortune or lack is liquidated. When the river goddess confirms the sincerity of the woman, she allowsher to take the water thereby the lack is resolved. 19

Return. $\downarrow$ (down arrow):Hero sets out for home. On getting the pot the woman returns home. 20

Solution N: Task is resolved.

The task is resolved; the woman brings the water home. $\mathbf{2 6}$

Recognition Q: Hero is recognized by his accomplishment of a difficult task.

The woman is recognized as the heroine as she brings the water. 27

Punishment U: Villain is punished. At the end, villainy (the first wife) is punished; this punishment is selfinflicted in that it was she who sends her daughter to go to that same spirit infested stream to fetch waterat an odd hour in which she is given two pots big and small she chooses the big pot containing calamitous object that results to their punishment. 30

Wedding W: Hero marries and ascends the throne. The end of this tale brings the hero celebrating. There is merriment as the woman comes back unharmed and her life transforms.31

The tale above has seventeen functions according to Propp (1928) structural model.

\section{Tale two:Ifemere Mbe ji nworo mkpokoro azu}

Oruru otu mgbe ụmụ anụ dum gbakọtara kpebia wọ gha atụkọta ego rụara Eze wọ Obi eze. Mbe họpụta Ngwụrụ gha ọbụrụ onye iche ego. Umu anụ kweta n'ihi ngwưrụ nwo ntogho ọkpa ugwu. Mgbe mbe chọpụtara eleghi ego wọ tụkọtara adịle ukwua, yọ gba izu o te ọ gha- esi zuru ego ọhụ mgbe onweghi onye gha anọ ụzọ. Ya kpọkọta ụmụ anụ kpaịị wọ eleghi Chineke ziri ya nrọ gha wọ kpe ekpere ma wọ emeghi otu ọhụ wọ amaghịarụpụta ife wọ bu obi. Mbe duru wọ baị ekpere ma zịa wọ gha wọ kpudo ifu alị dị- ịtụgharị uche, gọ ma wọababụtụkwara ma ọbụghị ma Chineke meturu wọ aka. Mgbe ụmụ anụ kpudoro ifu alị da-eche mgbe Chineke gha-emetu wọ aka, mbe gbara ọsọ je zuru ego ọhụ. Yọ were okpogho ọhụ je doo ulo ma gbaghachi ebe ọụ ụmụ anụ nọ da- eche gha Chineke metu wọ aka. Yọ were aja wọ ụmụanụ wọ echere eleghi ọbụ Chineke meturu wọ aka. Wọ gbọzọhụ lagha ulo wọ. Mgbe abalị olere ole gara Ngwuru chọpụta eleghi ego ọhụ adịnkwaghị. Yọ kụọ ekwe zịa nde ọha gọ okpogho ọhụ adịnkwaghị. Ụmụ anụ gbakọtama mbe bụ onye ọ ka ọjọ. Mgbe iwe ụmụ anụ kụlatara wọ kpọ Ọsa gha ọbụrụ onye oche ego. Ọsa were ego ọhụ je doo ya akwụnị ya elu osisi. Mbe gbakwa izu ọdọ ote o gha -esi ezuru ego ohụ. O mekwara ote o da-eme hapụ ụmụ anụ gha wọ dịekpe ekpere yikoro elu osisi ibe ọsa doro ego ọhụ. Yọ si elu daa ma kụwadụa mkpokoro azụ rua taa Mbe bụzụ mkpokoro azụ. 


\section{English version: The Reason for Tortoise's checkered shell.}

Once upon a time all the animals gathered for a meeting at which they decided to contribute some funds and build a palace for their king. Tortoise nominated Rat the treasurer and the other animals agreed because Rat has a big hole at the foot of the hill. When Tortoise felt that the money contributed was much, he thought up a plan of stealing the money in the absence of Rat when nobody would be on the road. He convened a meeting of all the animals and told them that God talked to him in a dream and asked them to pray otherwise they would not achieve their laudable venture of building the palace. He led them in prayers after which he asked the animals to mediate and that nobody should get up until God touched them. As the animals lay on the ground with their faces buried in the sand, Tortoise rushed to the hole and looted the public treasury. He took the money to his house before he returned to the venue of the meeting where the animals were waiting for God to touch them. He spread sand on them. So the animals presumed that the sand that touched them was the hand of God. They rose up and went home. Some days later, Rat realized that the money he kept for all the animals was missing. He sounded a metal gong round the community and informed all the animals that the public fund in his custody was missing. The animals gathered and Tortoise became most offended. When the anger of the animals lessened, they appointed Wren the next treasurer with the hope that he would do better. Wren collected the money and kept it in his nest on the top of a tree. Tortoise once again planned to loot the treasury. $\mathrm{He}$ repeated his strategy of prayers and left the animals to climb the tree on which Wren hid the money. Unfortunately, he fell down and broke his shell. Up till today the shell he wears is checkered.

This tale 'Why the Tortoise has checkered shell' has two moves just like Azuonye's Omalinze.

\section{First move:}

Absentation $\beta$ :A member of the family leaves the security of the home environment. This may be the hero or some other member of the family that the hero will later need to rescue.

The animals /Rat leave or leaves. 1

Interdiction $\square$ (gamma):An interdiction is addressed to the hero ('don't go there', 'don't do this'). The hero is warned against some action (given an 'interdiction').

The story begins with an agreement, the animals agreed to contribute fund to build a palace for their king. It is a common function in Igbo society that there must be agreement before a function is carried out. Interdiction is to approximate agreement and when interdiction is violated an agreement is also violated. 2

Reconnaissance $\square$ (epsilon): The villain makes an attempt at reconnaissance. The villain (often in disguise) makes an active attempt at seeking information. The villainy (Tortoise) makes an attempt at reconnaissance. He purposely suggested the rat to be the treasurer. This is a hidden agenda.He did this because he has already known where the rat keeps his money 4

Delivery $\square$ (zeta):The villain gains information about the victim. The villain's seeking now pays off and he or she now acquires some form of information, often about the hero or victim. Other information can be gained, for example about a map or treasure location.

The villainy gained information about the victim, he nominated the rat. Every animal accepts the nominationof rat as the treasurer. This clearly gave the tortoise the opportunity to know who holds the money and where the money is. 5

Trickery $\square$ (eta):The villain attempts to deceive the victim to take possession of victim or victim's belongings (trickery; villain disguised, tries to win confidence of victim).

The delivery gives room for trickery. The tortoise uses persuasion to convince every animal that rat is the most qualified to keep the money. 6

Complicity $\square \square$ (theta $\square \square$ the hero agrees with the villain's persuasions; the hero mechanically reacts to the employment of magical or other means (e.g. falls asleep, wounds himself).

The animals agreed to pray to God with their faces buried to the ground. 7

Villainy A:Villain causes harm or injury to family member (by abduction, theft)

Tortoisesteals the money. 8

Mediation B:Misfortune or lack is made known, The hero now discovers the act of villainy or lack, perhaps finding their family or community devastated or caught up in a state of anguish and woe. 
In this tale, misfortune or lack is made known the rat sounded the metal gong informing the animals about the missing money. The community on hearing that their hard earned money is stolen was devastated and was caught up in a state of anguish and woe. 9

\section{Second Move:}

Villainy A:Villain causes harm or injury to family member (by abduction, theft)

The second move of the tale starts with Villainy. At this juncture, the villainy (tortoise) causes harm to the community. This is not a physical harm but financial harm because he (tortoise) causes the community to suffer huge loss. 8

Beginning of counter-action C: Seeker agrees to, or decides upon counter- action. The hero now decides to act in a way that will resolve the lack, for example finding a needed magical item, rescuing those who are captured or otherwise defeating the villain. This is a defining moment for the hero as this is the decision that sets the course of future actions and by which a previously ordinary person takes on the mantle of heroism.

Since the last treasurer disappointed the community, they decided to appoint another treasurer in the person of squirrel. Nomination is again made by the Tortoise still with evil intention. 10

First function of the donor D: Hero is tested, interrogated, attacked etc., and preparing the way for his /her receiving of magical agent or helper (donor).

The squirrel on assuming the post of a treasurer places the money on top of the tree where no other animal can climb. 12

Victory I:Villain is defeated (killed in combat, defeated in contest, killed while asleep, and banished).

Villain (the tortoise) attempts to climb the tree where Squirrel keeps the money but falls from the tree and smashes his shell. This is a victory to the hero 'squirrel'.18

Recognition Q:Hero is recognized. From what happened to tortoise the community gets to know that it has been tortoise all this while. This gives way for the hero 'squirrel' to be recognized. $\mathbf{2 7}$

Exposure Ex: False hero is exposed.The false hero or villainy 'Tortoise' is exposed. 28

The second tale is a tale of two moves; the first move has eight functions while the second move has six functions.

\section{Tale three: Oriri Mbe yara Ụmụ nnụnụ.}

Oruru otu mgbe ụmụ nnụnụ chọ ije oriri elu ngwe mbe nụrụ ya chọ gha o soro ụmụ nnụnụ je oriri elu ngwe. Obi adịdụghị Ụmụ nnụnụ mma ma wọ nabatara gha Mbe soro wọ jegha. Izu akaraka rua Mbe pụta rị̣tụ Ưmụ nnụnụ gha wọ nyetu ya nku gha o nwe ike isoro wọ jegha. Wọkweta ịgbazịmbe nku. Wọ họputa Mbe gha ọ bụrụ onye nkwuchite ọnụ, Mbe ziri wọ eleghi omenali nde wọ gahere ọbịa bụ eleghi wọ gha enwe afa ơfụrụ nge nge. Yọ ghọgbu ụmụ nnụnụ nde amaghịife o bu uche gọ afa ya bụ "Ụnụ dum". Mgbe wọ rutara nde wọ bịara ibe wo nabatara wọ nke ọma. Wọ butara wọ ife oriri yara ife ọnụu si wọ ife oriri a yara ife ọnụu a bụ nke "Ụnụ dum". Mbe si ụmụ nnụnụ gha wọ nwotu ndidi gọ nke wọ gahi.Yo ridua nri yara ife ọnụnụ dum ka onwo nke ọ hapụrụ Ựụ nnụnụ. Mgbe mmemme gwuru Ụmụ nnụnụ wea oke iwe eleghi o nweghi ife wọ riri. Mgbe oge ụla ruru wọ kpebia wọ gha- emegwara ife mbe mere wọ site ị nara ya nku wọ. Mgbe wọ laghe Mbe amaghịkwa ife ọ gha-eme yọrịtụ ụmụ nnụnụ gha wọ zia nde ụlọ ya gha wọ kpokọta matarasi ibe olu gha ya nwea ike si elu wudata matarasi ọhụ. Wọ kwetara izi ozi Mbe duiri wọ. Mgbe wọ laruru ulo, wọ zịa ezinulo Mbe gọ Mbe siri gha wọ kpokọta ife dum kụwara akụwa ite, efere, nma yara ife dum e meru ụhụ. Ezinulo Mbe kpokọtadụa ife dum da-emeru ụhụ. Mbe chere eleghi ozi o ziri anwụrụ ọkụ ruru elungwe si elu wụdata. Yọ daa elu ife dum nde ọhụ da-emeru ụhụ ma kụwa okpokoro ya.

The structural analysis of the third tale begins with delivery.

Delivery $\square$ (zeta):The villain gains information about the victim. The villain's seeking now pays off and he or she now acquires some form of information, often about the hero or victim.

This tale starts with the villainy gains information about the victim; the villainy tortoise) gets information about the birdsgoing for a feast in the sky.5

Trickery $\square$ (eta):The villain attempts to deceive the victim to take possession of victim or victim's belongings (trickery; villain disguised). The villain now presses further, often using the information gained in seeking to deceive the hero or victim.

The information the villainy gained helped him to deceive the birds (victims) he dispossesses the birds of their belongings. He does this by telling them that each person must take a name, he informs them that it was a tradition of their host to have title names. 6

Complicity $\square$ (theta):Victim taken in by deception, unwittingly helping the enemy. The trickery of the villain now works and the hero or victim naively acts in a way that helps the villain.

DOI: 10.9790/0837-2107020112 www.iosrjournals.org 10 |


Here the trickery of the villain works the birds are deceived they (birds) are taken in by deception by taking titular names. He (Tortoise) takes, "All of you" while others take other gigantic names. 7

Villainy A:Villain causes harm or injury to family member.

In this tale villain causes harm to the victims (the birds) because whenever anything was brought to the birds whether food or meat tortoise will first ask "to whom are you serving this". And they will say to "All of you" and he will tell his colleagues that the tradition was that they want to serve people one by one, that they will serve them later. The birds are starved. 8

Mediation B:Misfortune or lack is made known. The hero now discovers the act of villainy or lack, perhaps finding their family or community devastated or caught up in a state of anguish and woe.

The victims (birds) discovered the truth. They are devastated and caught up in a state of anguish and woe. 9

Beginning Counter-action C:Seeker agrees to, or decides upon counter- action. The hero now decides to act in a way that will resolve the lack, otherwise defeating the villain.

The birds feeling devastated decided on leaving tortoise behind by each of them taking the feathers they contributed which enabled him to fly. 10

Departure $\uparrow$ (up-arrow):Hero leaves home. They (Birds) leave. 11

Struggle H: Hero and villainy do battle. The battle here is not a physical warfare but a test of wit. They are now tested who has more sense than the other. This is because tortoise had told the birds to tell his people to bring out soft landing materials for him to land but on the contrary the members of tortoise family were asked to bring out all the iron or hard materials and heaped them on the landing base.16

Victory I: The villainy is defeated. He landed on the hard landing base which members of his family have prepared for him.18

Resolution K: Initial misfortune or lack is resolved. The birds now have vengeance on the tortoise for keeping them hungry. 19

Finally, the third tale has ten functions.

\section{English version: The feast Tortoise and Birds:}

Once upon a time, birds planned to attend a feast in the sky. Tortoise heard of the meeting and begged birds to allow him join them. They did not like it but after some considerations, they allowed him to attend in their company. On the said day, Tortoise came out and begged some birds to lend him feathers. They obliged him feathers. They elected Tortoise their spokesman and he told them that the culture of their prospective hosts was that they should take new names. He deceived the birds who were unaware of his intention. He then took his new name of "All of you".

When they arrived, their hosts received them cordially. They present food and drinks and told Tortoise and birds that the food and drinks were for him because his name was "All of you". Tortoise told the birds that the food and drinks were for him because his name was "All of you". He told the birds to exercise patience for the shares would be brought later. He then ate and drank as much as he could leave little or nothing for the birds. At the end of the feat, birds ate nothing and got angry. When it was time for them to fly, they decided to revenge by taking back their respective feathers.

As they were going home Tortoise was stranded and he begged them to tell his people to gather foams in one place so that he could jump from the sky to land on the mattress. They agreed to deliver his message. When they reached home, they went and told Tortoise's family that Tortoise asked them to gather all the broken pots, plates, knives and anything that can injure. The family of Tortoise gathered every dangerous object together for him. Tortoise thinking that his message was safely delivered decided to jump down. He crashed on the dangerous objects and broke his shell.

\section{SUMMARY AND CONCLUSION}

One of the findings of this work is our contribution on an on-going debate concerning the reasons why tales told all over the world look alike. From our study we have realized the reality of the claim that folktales told all over the world are alike in content, in structure, and in style of rendition. From the above analysis, we have seen how some of the structural functions identified by Propp fit properly into Igbo folktales. Propp's analysis was a guinea pig to show that what people think of folktale is not true. They describe it as old woman or little children tale, and unrealistic and therefore regard it as something that should be thrown away. The structural analysis of Igbo folktales and folktales all over the world has shown that folktales have more in it than what people have imagined.Folktale has been the traditional tool African societies employ to entertain, educate as well as transmit their traditions, cultures and values to their succeeding generation. This baton is in our hands but unfortunately the present generation exhibits gross insensitivity to this rich heritage. Thus, the values and wisdom enshrined in these art forms are on the brink of extinction where a good number has been. In this age of diverse technological breakthrough and globalization the present African generation is confronted with a maze 
of strange cultural values, which has resulted in lack of knowledge of self and blind imitation of culture. Imagine the Igbo folktales in all dialectal varieties passing through the beauty of structural analysis. In each of these tales reside unique traditions and cultural values that refer to all aspects of human existence. However, the strength of this art form is that the lesson to be derived are not restrictive, the stories are timeless and could apply universally. There should be massive sensitization of the Nigerian populace on our own cultural values with the aid of folktales. The need to project as well as utilize this heritage should be emphasized for at performance: the cultural values are retrieved, transmitted and invariably developed.

\section{REFERENCES}

[1] Achebe, C. (1987).Anthills of the Savannah. London: Heineman Publisher

[2] Aku, F. (2011). Folktales in the Caribbean. Journal of folklore, 2. Pp90-120.

[3] Ashton, J. N. (1957). Folklore in the Literature of Elizabeth England.Bloomington: Indiana University Press.

[4] Azuonye, C. (1990). Morphology of the Igbo folktale: ethnographic,historigraphic and aesthetic implication. Folklore,Vol.101. No.2, pp. 36-46

[5] Cornell, C. (1993). Language and culture monsters that lurk in our traditional rhymes and folktale. New York: Young Children Detroit.

[6] Dorson, R. (1972). Current theories of folklore in folklore and folklife. Chicago: University Press.

[7] Dundes, A. (1976). Structuralism and Folklore in Folk narrative research. London: Studia Fennica 20 Heisinki.

[8] Edeoga, P. (2015). The structuralist analysis of "Odu na Ona". A paper presented on the 9 ${ }^{\text {th }}$ Igbo Studies Association (ISA) Annual Conference and General Meeting at the University of Nigeria, Nsukka on $23^{\text {rd }}-26^{\text {th }}$ September, 2015.

[9] Egudu, R. (1973). The calabash of wisdom and other stories. New York: NKO Publishers.

[10] Eze, E. (2000). A syntagmatic approach to the study of Igbo folktales. M.A. Thesis unpublished. University of Nigeria, Nsukka.

[11] Ikeokwu, E. S. (2007). Functionalism and the pedagogy of Igbo folktales. Journal of Igbo studies (JIS) 2, 21-26.

[12] Iwuchukwu, U. (2008). The thematic and stylistic analysis of folktales of Oraifite dialect of Igbo language. B.A. project unpublished. Ebonyi State University, Abakaliki.

[13] Iyasere, S. (1975). Oral tradition in the criticism of African literature. ThAe Journal of Applied Studies. Ibadan: University Press.

[14] Mbah, B. and Mbah, E. (2007).Azuonye: Lectures on Igbo literature and stylistics. Nsukka: University of Nigeria Press Ltd.

[15] Mbunda,F.(2002). Wonder tales of Oku and aesthetics of storytelling.Enugu: Keny Brothers.

[16] Nwaozuzu, G. I. (2006). The Child as an Image of Innocence and Credulity in Igbo Folktales. Journal of Igbo StudiesAssociation, Vol.1 Nsukka: Ifedimma Comm.

[17] Nwaozuzu.G.I. (2007). The traditional Igbo woman - a villain or victim: A study of the image of women in folktales. Journal of Igbo studies (JIS). 2, pp 27-33

[18] Ogbalu, U. (2011). Appreciation of Igbo folktales and songs versus realism. Ujah, Unizik Journal of Arts and Humanities. Vol 12 no. 1 .

[19] Propp, V. (1958).Morphology of the folktale. Austin: University ofTexas Press.

[20] Thompson, S. (1951). The folktale. New York: Dryden Press.

[21] Ugochukwu,C. and Oguine, P. (1972). Omalinze.A book of Igbo folktales. Ibadan: Oxford University Press.

\section{Informants:}

[22] Ụkpaị Ụka. 70 years, Farmer, Akanụ Owutu Edda.

[23] Anya Eseni Ụkwa, 65 years, Retired Teacher, Itim Edda.

[24] Okam Egwu Onu, 65 years, Farmer, Ekoli Edda.

[25] Agwu Ịbịam, 70 years, Retired Town Crier. Ekoli Edda. 